\title{
UTILIZATION OF DEFENSE INFRASTRUCTURE COMPONENTS AT THE TIME OF THE CRISIS SITUATION
}

\section{Jan Brezula}

Security and Defence Department, Armed Forces Academy of General M. R. Stefanik in Liptovsky Mikulas, Slovak Republic

OMESTE

JEL Category: H56

\begin{abstract}
Critical infrastructure is inescapable for the preservation of the essential functions of society, health, safety and life quality of the population from an economic and social point of view and its disruption or destruction would have serious consequences for the Slovak Republic due to the impossibility of preserving its functions. The defense infrastructure, as the part of the critical infrastructure, is a necessary element of supporting state defense and it is formed by the services and activities provided to the Slovak Armed Forces for ensuring effective protection and defense of the Slovak Republic. The defense infrastructure consists of land, buildings and facilities, telecommunications, energy and transport systems, information networks and supplies of state material reserves. An important part of the defense infrastructure are the services and activities provided to the armed forces to provide state defense. These services and activities include financial, medical, veterinary, transport, telecommunication, postal, supply, accommodation, research and scientific services, manufacturing, repair and construction activities.
\end{abstract}

Keywords: Infrastructure, defense, risk, facilities, global environment, strategy

\section{INTRODUCTION}

The Slovak Republic has become a member of NATO as a part of a collective defense and security system in 2004. The same year, it was also accepted as a member of the European Union. By its membership it has obtained political and economic stability guarantees as well as the possibility to actively participate in shaping,

Address of the author:

Ján Brezula

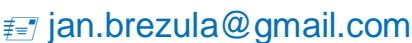

implementing and strengthening the European Security and Defense Policy. This fact did not mean only the integration in the well-established community of Western European states, but in addition to the advantages and wider possibilities, it also meant signing up to the common direction and fulfilling their ambitions, including the defense and protection of critical infrastructure. On these changes, the Slovak Republic responded to the preparation and adoption of new strategic documents - a security and defense strategy. Developments in the global security situation, 
changing the nature of threats and risks have prompted the need for effective protection and defense. In addition to traditional threats such as natural disasters, negligence, technological accidents, unauthorized penetration into computer systems or criminal activity, a new threat emerged on the security scene -international terrorism. This phenomenon focuses its efforts in addition to traditional objectives, particularly on the critical infrastructure of the states, in order to cause mass sacrifices, damage, to create fear and a sense of danger. An important part of an effectively functioning defense system of the Slovak Republic is defense support, which also includes critical infrastructure. The mission of defense support in the state defense system is to provide adequate means, services and activities for the fulfillment of the state tasks in the framework of the defense of state sovereignty and also during the operation of Allied Forces in the Slovak Republic.

\section{GLOBAL ENVIRONMENT}

The global security environment is characterized by high instability, uneven development, and high dynamics of ongoing changes, the complexity of ongoing security processes. While the risk of conventional large-scale war is relatively low, it is not possible to exclude the escalation of tensions through potential regional conflicts with a direct impact on Euro-Atlantic stability. Enlargement of Russia's sphere of interest and influence, hybrid and non-military threats, terrorism, mass migration, the spread of extremism and radical ideologies as well as social turmoil, resulting from the unstable economic situation and globalization, can pose a significant security risk for all European states. These threats can arise very quickly and dynamically and are hardly identifiable or predictable. Increasing uncertainty and unpredictability of the security environment, turbulent and difficult predictable development of the situation in Ukraine, Syria, the countries of Africa, the Near and the Middle East, ethnic unrest, extremism, etc. create the prerequisites for a rapid reaction of the international community (Trebula, 2016). The instability of the countries close to the Euro-Atlantic area, as evidenced by recent developments in Syria, the Middle East, and the Middle East, can have a direct impact on our security, particularly in terms of the rise in extremism, terrorism, arms and drugs smuggling, trafficking in human beings and illegal immigration. An increase in coordinated cyber attacks, as a very effective tool for disrupting the work of government administrations, the economy, and the critical infrastructure, is also a current threat to the Euro-Atlantic area. Disruption of key state infrastructure objects due to a terrorist attack or other reasons, a major natural disaster or a technological breakdown in the state would always mean great losses on life and property, moral damages, or would lead to disorganization of society as a whole. The destruction of state infrastructure may endanger food production itself, heating, industrial production and, in fact, distort of the whole society. The collapse of any state may result in infrastructure failures at a transnational scale, also in the wider geographical area, which is interconnected by different networks. The infrastructure of each individual state is highly vulnerable and very interconnected, both inside and outside and necessary for the operation of the society. Terrorist groups have proven they are capable of coordinated attacks at the same time in different locations. Planning attacks long-term ahead, targeting even a few years, they consider all factors to minimize their own efforts and maximize profits.

The protection and defense of critical infrastructure elements are based on the principles that:

- the protection and defense of critical infrastructure is primarily the national responsibility of the individual state and it is a part of the common European framework,

- the public administration (government, prosecutor's office, courts, ministries, armed forces, security corps, etc.) is responsible for the protection and defense of the critical infrastructure together with the owners and operators of the individual critical infrastructure elements,

- information concerning the protection and defense of critical infrastructure and its exchange must be protected against misuse,

- the protection and defense instruments shall be set proportionally to the level of risk involved. 


\section{PRINCIPLES OF THE PROTECTION AND DEFENSE OF CRITICAL INFRASTRUCTURE}

The protection and defense of the critical infrastructure are understood as a summary of the activities, mechanisms, forces, means, and measures for:

- prevention of risk factors,

- averting an attack on a critical infrastructure element,

- avoiding negative external or internal influences endangering the existence, stability, and operation of the critical infrastructure element.

The protection of individual elements of critical infrastructure is organized in full by a legal person, owner or administrator as part of its own property protection measures. The defense of critical infrastructure elements is realized for objects classified as objects of special importance and for other important objects. These are objects that have a strategic importance in the time of the war for the defense of the state, the activities of the armed forces or the functioning of the state economy (Zibrík, 2011). The critical infrastructure protection can be understood as a set of measures provided by the owner of the facility, private security services, and designated police units to protect the assets of defense infrastructure objects classified as objects of special importance and other important objects. It is carried out continuously both in the state of safety and during the crisis situation.

The objective of protecting critical infrastructure is to:

- prevent intrusion into the facility and to prevent activities in the facility by not allowing individuals or groups,

- reduce or prevent the emergence of seamless risk / terrorist attack, sabotage, theft, and others,

- ensure the functionality of the technology and the usability of stored stocks,

- ensure the safety of the operation and the resulting safety of the inhabitants' residence in the vicinity of the objects,
Object protection is divided into basic and enhanced property protection. Protection is divided by security method to:

- protection of objects classified as objects of special importance,

- protection of objects classified as other important objects.

Basic property protection of objects means the protection, in particular, of classical theft, unauthorized access to information forming business secrets and unauthorized access to information systems. Basic property protection is organized and funded in full by a legal entity, owner, or property manager as part of its own property protection measures.

Enhanced property protection is understood to be measures taken to avoid the creation of barriers to the capability and determination of the object in terms of the interest and needs of the state, the loss of some of the capabilities.

The measures for enhanced property protection of objects are mainly directed against the attempt:

- an unauthorized person disrupt the integrity of the object, or attempt to enter the premises by overcoming mechanical barriers,

- an unauthorized vehicle to enter the facility may interfere with its integrity by overcoming mechanical barriers,

- the unlawful bringing of dangerous substances into the facility,

- the illegal removal or export of dangerous substances from the object, threatening the operation of the assigned object.

The main elements of enhanced property protection are:

- reinforcement of mechanical and preventative means,

- electronic security systems,

- human resources,

- organizational arrangements,

- connection to the police registration alarm centers,

- the preferential and effective intervention of the forces and means of the police corps in the event of a crisis situation that can not be managed by the forces and means of the 
physical protection unit located in the object (asymmetric attack).

The defense of strategic critical infrastructure objects (objects of special importance and other important objects) is a set of measures that are planned and performed by the designated units or departments of each individual state with the intention of discouraging, mitigating or repelling the enemy's attack and thus preventing the occurrence of undesirable consequences due to acts of violence.

The aim of defense is:

- not to permit the movement and maneuvering of access to the object and the prevention of intrusion into the object of unauthorized and armed individuals or groups,

- to slow down, stop or repel an attack by armed individuals or groups trying to control the object,

- to disarm armed individuals or groups who have entered the premises,

- to restore and secure the security of the object.

When occupying the area of defense, building a defense, and conducting combat activities to defend designated objects, the commander uses the knowledge, information, and recommendations of the Head of the security service. If the threat of a terrorist attack persists or there is reasonable suspicion that the designated objects will continue to be the target of the armed terrorist group even after dissuading them, the commander of the unit defending the object will create a system of regime measures. Implementation of regime measures will be ensured by the commander of the unit by monitoring, patrolling and creating a network of control points.

\section{DEFENCE INFRASTRUCTURE IN SLOVAK REPUBLIC}

As a part of the preparation for state defense, it is mandatory to select and classify elements of objects of special importance or other important objects for state defense and determine the way of their protection and defense. Updating the inclusion of defense infrastructure elements into individual categories and how they are protected and defended is performed annually. The ranking list describes how to protect and defend the defense infrastructure element in a time of security, state of emergency, war, and counterterrorism. The aim is to ensure that the protection of these objects is ensured using modern technologies, but especially that the electronic security systems are connected to the centralized protection of the police corps in order to perform an effective intervention of predetermined forces and means in case of disruption of the object. Mechanical barriers must be built in such a way that they can not be overcome unjustifiably in a time shorter than the time required for reliable detection and observation of an intruder by industrial television or by members of physical protection. At the same time, a range of documentation is set up to ensure the protection and defense of objects. Plans for the protection and defense of objects are classified information. Information from these plans is sensitive information and is available under a special regulation (Brezula, 2017).

Based on the content definition of critical infrastructure, it is clear that the Slovak Armed Forces will participate in the maintenance of the public order and internal security of the state. The Slovak Armed Forces, as one of the main authorities for protecting and defending defense infrastructure elements, is likely to be involved in reducing the risk of endangering the existence and stability of defense infrastructure elements or averting attacks on defense infrastructure elements or their system of protection and defense.

Based on this goal, it is possible to identify the use of the Slovak Armed Forces in securing tasks related to the defense of defense infrastructure elements such as:

- a tool to reduce the risk of endangering the existence and stability of an element,

- a tool to avert an attack on an element or its system of protection and defense by reacting and interfering with a possible attack.

The Slovak Armed Forces will be used to support other state authorities to eliminate these threats:

- in case of threat of possible terrorist attacks,

- in the event of internal unrest that threatens the democratic foundations of the state caused by extremist groups, 
- in the event of mass and uncontrollable migration of the population,

- in the event of natural disasters, industrial accidents, disasters, and extensive forest fires.

Based on the scenarios of possible threats, individual types of plans are developed for each type of threat. At present, the following types of plans are used in the Slovak Armed Forces:

- the plan of the Slovak Armed Forces in case of a terrorist attack,

- the plan of the Slovak Armed Forces for the mass migration of persons,

- the plan of use of the Slovak Armed Forces at an emergency time in the event of natural disasters,

- the plan of the Slovak Armed Forces at the time of emergency in case of accident and disaster,

- the schedule of using of the Slovak Armed Forces in a state of emergency in large forest fires.

\section{DEVELOPMENT OF CAPACITY AND REQUIREMENTS FOR THE SLOVAK ARMED FORCES}

As mentioned hereinabove, the current security risks focusing on the deteriorated situation in Central Europe, the issue of the protection and defense of critical infrastructure needs to be addressed as a matter of priority and without delay. Its disruption, destruction, or disrepair would cause partial or total failure of state security. For this reason, it is necessary to conceptually solve the security situation, to ensure the preparedness of the protection and defense of the defense infrastructure in all areas so that the subsequent response to the targeted and conducted terrorist attacks on the defense infrastructure is effective (Marchevka, 2015).

Based on the current situation in the defense sector in the field of security and performance of tasks in relation to defense infrastructure, we propose and recommend the basic requirements capability development in the following areas:

1. The definition of the responsibility of individual organizational units in the process of command in the field of defense infrastructure is currently not determined by any internal regulation that would define concrete responsibilities and specific tasks in relation to the protection and defense of the defense infrastructure elements.

Recommendations:

- to appoint a person responsible for the elaboration of the defense infrastructure development concept in the defense sector of the Slovak Ministry of Defence,

- to create a joint commission with the participation of all the departments of the ministry to fulfill the task,

- to carry out a thorough analysis with a focus on the current state of affairs with a proposal to eliminate the persistent deficiencies in the management and security of defense infrastructure,

- to adjust legislation, the doctrinal environment that ensures the fulfillment of given tasks,

- to define the specific roles and responsibilities of individual officials at each level of control and command,

- to carry out regular joint inter-ministerial negotiations with elements corresponding to the individual areas.

2. Recent analyzes of the security system of the Slovak Republic have pointed out, among other things, that it lacks the necessary institutional framework for fulfilling critical crisis management/defense infrastructure tasks. At the same time, the Slovak Armed Forces as a tool for implementing a real and practical defense of critical/defense infrastructure in the event of a non-military crisis situation does not have a firm position in crisis management.

Recommendations:

- it is necessary to initiate the initiative for the implementation of critical infrastructure into the domestic crisis management system and consequently to the process of incorporating the Slovak Armed Forces into the Integrated Rescue System as an integral part of supporting the state defense.

3. The current material and technical equipment of person responsible for central evidence of the defense infrastructure does not allow to 
fulfill tasks related to work with data-intensive websites (eg: road network portal).

Recommendations:

- to ensure certified computing equipment able to connect to the classified network with emphasis on the transmission and distribution of classified data from the central register for responsible officers in the Slovak Ministry of Defence.

\section{STRATEGIC DEVELOPMENT OF DEFENSE AND SECURITY OF THE SLOVAK REPUBLIC}

Defensive planning is a specific system of planning and allocating financial, material and human resources to safeguard the defense of freedom, independence, territorial integrity and the democratic system of the state, the fundamental rights and freedoms of its citizens guaranteed by the constitution of the state, the spiritual values of society, life, health and property of persons public property and the environment in the event of invasion or threatening the state with alien powers (Školník\& Belan, 2015).

Defensive planning at the same time represents the processes and procedures by which individual states (pacts, communities, and alliances) fulfill their role in the defense of the state. It encompasses a wide variety of steps and measures, ranging from administrative ones, such as the legislative regulation of laws, regulations, standards, or actions and practices of individual public administrations, to physical material measures consisting, for example, of building defense infrastructure objects.

Defensive planning is one of the most complex and most important areas in this respect because it is essentially overlapping with almost all the activities of the state. Its complexity lies in the fact that individual measures need to be reconciled with a large number of overlapping and sequential steps. Its importance lies primarily in the fact that many measures take effect only after a few years from the start of their implementation and, on the contrary, their omission or mistakes in the implementation of some measures will be negative only after a few years but with more serious consequences.
Defensive planning is a system designed to make the military system more transparent and to make military spending transparent. It allows the distribution of military expenditures on operational, necessary for the common life of the army, and for development, intended for arms and modernization projects. With regard to defense planning processes, the Parliament approves not only the total amount of the defense budget but also the individual programs through which the objectives set are to be achieved. It emphasizes that the strategic objectives are set by the armed forces. At the same time, defensive planning is characterized as a system that allows a rational balancing of defense requirements with available financial, material and human resources. What is more, it ensures the availability and efficiency of the use of resources that are allocated to the defense.

The basic processes of defense planning are:

- planning, which represents long-term (strategic) planning,

- programming that represents medium-term planning,

- budgeting, which represents short-term planning.

Long-term strategic planning is based on the defensive policy of the state, its defense and security objectives, defense visions, security strategic environment, economic and security forecasts, concepts of planned forces structure, technologies, and so on. Long-term plans are generally set up for 10 to 15 years in Alliance member countries.

Medium-term planning is based on directives for state defense policy, basic governance documents and alliance requirements, state defense assessments, state legislation, state resources available, and the demands of the armed forces. It is focused on the realization of objectives and tasks resulting from long-term plans through programming. Programming is the process of implementing programs and projects, which results in a balanced process and the effective distribution of available resources to provide the required capabilities and capabilities of the armed forces and to support the defense of the state. Medium-term plans are generally set up 
in the member countries of the Alliance for a period of 3 to 6 years.

Short-term planning is based on long-term and medium-term plans, allocated financial resource limits and set priorities. It is aimed at elaborating financial plans, drafting, and budgeting of individual programs, sub-programs, projects and program elements. Short-term plans are generally set up in the member countries of the Alliance for a period of 1-2 years.

The basic solution for the development of the Slovak Ministry of Defense is the defense and capabilities requirements of the Armed Forces arising from the Defense Strategy of the Slovak Republic, generally binding legal regulations and international obligations and other relevant defense policy and planning documents.

The Slovak Republic secures its defense in NATO's collective defense system. The need to face all threats, challenges, and risks to the Slovak Republic, wherever these arise, creates increased qualitative and quantitative requirements for capabilities of the Slovak Armed Forces. The character of combat activity in international crisis management operations increases pressure on the development of new capacities of the Slovak Armed Forces, with an emphasis on deployability and sustainability in operations far from the territory of the Slovak Republic. NATO and the EU, in response to this development, apply a comprehensive approach using a wider range of tools and mechanisms, including the development of new, highly sophisticated and resourceintensive defense capabilities.

Designated units of the Slovak Armed Forces will most likely be transmitted to peace support operations and anti-terrorist operations, with a focus on crisis prevention, stabilization, and reconstruction efforts. Priority in the Slovak Armed Forces capacity development remains the building of deployable and sustainable forces in the forces of high preparedness and their potential deployment and maintenance in operations outside the territory of the Slovak Republic. These forces will be universally equipped, staffed and trained to respond quickly to emerging crises and will be prepared to effectively fulfill the roles of international commitments with emphasis on NATO and the EU.

\section{CONCLUSIONS}

For the reason of the current security risks and worsening of the situation in Central Europe, the issue of the protection and defense of defense infrastructure needs to be tackled as a matter of priority (Sahin, 2017). That is why, because its disruption, destruction, or disrepair would cause partial or total failure of state security. Hence, it is necessary to conceptually solve the security situation, to ensure the preparedness of the protection and defense of the critical/defence infrastructure in all areas. The issue of protection and defense of critical/defense infrastructure is extremely wide. In spite of it, the elements of the critical infrastructure and the tasks necessary for protection and defense have been clearly identified in the Slovak Republic in the recent years. However, it should be remembered that the protection of critical or defense infrastructure is not a one-off activity, but it is a process that requires constant attention. This means that the defense infrastructure operators themselves need to constantly address this issue and continually develop its methods and to incorporate the latest trends and knowledge in the field.

\section{WORKS CITED}

Brezula, J. (2017). Prvky obrannej infraštruktúry a ich vedenie $v$ ústrednej evidencii: Zborník vedeckých a odborných prác Národná a medzinárodná bezpečnost' 2017, (pp. 32-37). Liptovský Mikuláš.

Marchevka, M. (2015). Vytváranie zásob pre krízové situácie: Zborník vedeckých a odborných prác Národná a medzinárodná bezpečnost' 2015, (pp. 381-388). Liptovský Ján.

Sahin, S. (2017). Public international law and the self- proclaimed newly declared republics: Zborník vedeckých a odborných prác Národná a medzinárodná bezpečnost' 2017, (pp. 396-501). Liptovský Mikuláš. 
Školník, M., Belan, L. (2015). Obranné plánovanie. Základy plánovania a projektovania v systéme obrany a bezpečnosti SR. Liptovský Mikuláš.

Trebula, M. (2016). Metódy optimalizácie materiálového manažmentu aplikovatel'né $v$ podmienkach vzdušných sil Ozbrojených síl Slovenskej republiky: Zborník vedeckých a odborných prác Národná a medzinárodná bezpečnost' 2016, (pp. 533-543). Liptovský Mikuláš.

Zibrík, P. (2011). Podpora obrany štátu v podmienkach SR na začiatku 21. storočia. Zborník príspevkov z medzinárodnej vedecko-odbornej konferencie Manažment, teória, výučba a prax 2011, (pp. 215-221). Liptovský Mikuláš.

Received for publication: 16.12.2017

Accepted for publication: 10.01.2018

\section{How to cite this article?}

Style - APA Sixth Edition:

Boychuk, M., \& Yaroshenko, O. (2017, July 15). Modeling of optimal credit strategy of a pharmaceutical Brezula, J. (2018, Jan 15). Utilization of defense infrastructure components at the time of the crisis situation. (Z. Čekerevac, Ed.) MEST Journal, 6(1), 7-14. doi:10.12709/mest.06.06.01.02

Style - Chicago Sixteenth Edition:

Brezula, Jan. 2018. "Utilization of defense infrastructure components at the time of the crisis situation." Edited by Zoran Čekerevac. MEST Journal (MESTE) 6 (1): 7-14. doi:10.12709/mest.06.06.01.02.

Style - GOST Name Sort:

Brezula Jan Utilization of defense infrastructure components at the time of the crisis situation [Journal] // MEST Journal / ed. Čekerevac Zoran. - Belgrade : MESTE, Jan 15, 2018. - 1 : Vol. 6. - pp. 7-14.

Style - Harvard Anglia:

Brezula, J., 2018. Utilization of defense infrastructure components at the time of the crisis situation. MEST Journal, 15 Jan, 6(1), pp. 7-14.

Style - ISO 690 Numerical Reference:

Utilization of defense infrastructure components at the time of the crisis situation. Brezula, Jan. [ed.] Zoran Čekerevac. 1, Belgrade : MESTE, Jan 15, 2018, MEST Journal, Vol. 6, pp. 7-14. 